\title{
HCN1-mediated interactions of ketamine and propofol in a mean field model of the EEG
}

\author{
Ingo Bojak ${ }^{1,2,3^{*}}$, Harry C Day ${ }^{2}$, David T J Liley ${ }^{4,5}$
}

From Twenty Second Annual Computational Neuroscience Meeting: CNS*2013

Paris, France. 13-18 July 2013

Ketamine and propofol, two popular anesthetic agents, are generally believed to operate via disparate primary mechanisms: ketamine through NMDA antagonism and propofol through the potentiation of $\mathrm{GABA}_{\mathrm{A}}$-gated receptor currents. However, surprisingly the effect of ketamine on the EEG is markedly altered in the presence of propofol. Specifically, while ketamine alone results in a downshift of the peak frequency of the alpha

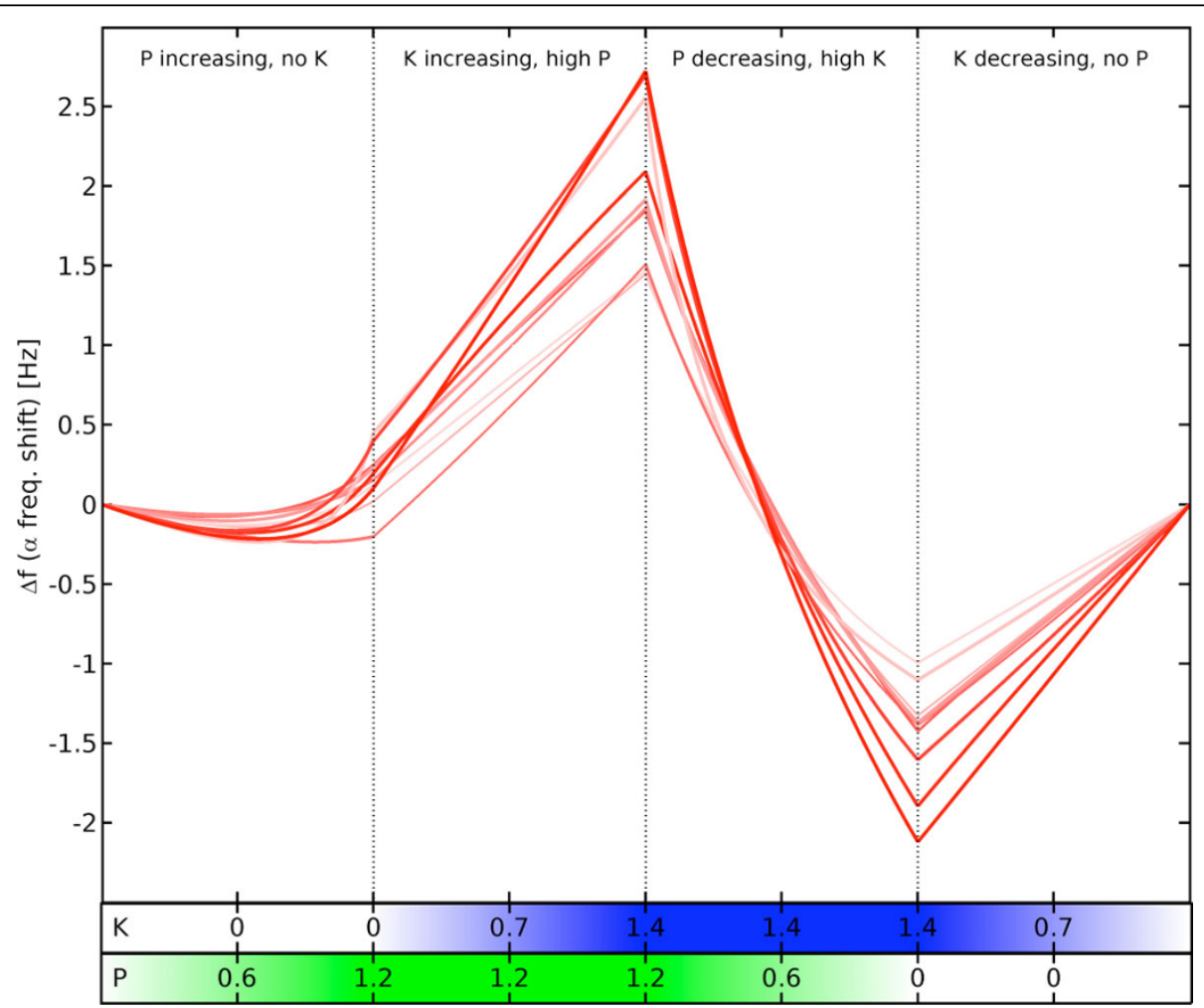

Figure 1 Predicted shift of the alpha peak frequency of ten parameter sets during four phases of linear change to the normalized ketamine $(K)$ and propofol $(\mathrm{P})$ concentrations, respectively.

\footnotetext{
* Correspondence: hxd215@bham.ac.uk

${ }^{1}$ School of Systems Engineering, University of Reading, Whiteknights,

Berkshire, RG6 6AY, UK

Full list of author information is available at the end of the article
}

(c) 2013 Bojak et al; licensee BioMed Central Ltd. This is an Open Access article distributed under the terms of the Creative Commons 
rhythm, and propofol keeps it roughly constant - when administered together, they increase the alpha peak frequency [1].

Recently it has been found that both ketamine and propofol inhibit the hyperpolarization-activated cyclic nucleotide-gated potassium channel form 1 (HCN1) subunits, which induces neuronal membrane hyperpolarization [2]. Furthermore, HCN1 knockout mice are significantly less susceptible to hypnosis with these agents; but equally affected by HCN1-neutral etomidate [2].

We show here [3] that an established mean field model of electrocortical activity can predict the EEG changes induced by combining ketamine and propofol by taking into account merely the HCN1-mediated hyperpolarisations, but neglecting their supposed main mechanisms of action (NMDA and $\mathrm{GABA}_{\mathrm{A}}$, respectively). See Figure 1.

Our results suggest that ketamine and propofol are infra-additive in their HCN1-mediated actions. This is consistent with independent experimental evidence [4]. We show here that the HCN1-mediated actions of ketamine and propofol, hitherto neglected by models of anaesthetic action, can not only explain a range of counterintuitive induced EEG changes but also predicts the infra-additivity of these drugs.

\section{Author details}

'School of Systems Engineering, University of Reading, Whiteknights, Berkshire, RG6 6AY, UK. ${ }^{2}$ School of Psychology (CNCR), University of Birmingham, Edgbaston, Birmingham B15 2TT, UK. ${ }^{3}$ Donders Institute, Radboud University Nijmegen (Medical Centre), 6500 HB Nijmegen, The Netherlands. ${ }^{4}$ Brain \& Psychological Sciences Research Centre, Swinburne Uni. of Tech., Hawthorn, Victoria 3122, Australia. ${ }^{5}$ Cortical Dynamics Ltd., Suite 4, 462 Burwood Road, Hawthorn, Victoria 3122, Australia.

Published: 8 July 2013

\section{References}

1. Tsuda N, Hayashi K, Hagihira S, Sawa T: Ketamine, an NMDA-antagonist, increases the oscillatory frequencies of alpha-peaks on the electroencephalographic power spectrum. Acta Anaesthesiol Scand 2007, 51(4):472-481.

2. Chen $X$, Shu S, Bayliss DA: HCN1 channel subunits are a molecular substrate for hypnotic actions of ketamine. J Neurosci 2009, 29(3):600-609.

3. Bojak I, Day HC, Liley DTJ: Ketamine, propofol and the EEG: a neural field analysis of HCN1-mediated interactions. Front Comput Neurosci .

4. HendrickX JF, Eger El, Sonner JM, Shafer SL: Is synergy the rule? A review of anesthetic interactions producing hypnosis and immobility. Anesth Analg 2008, 107(2):494-506.

doi:10.1186/1471-2202-14-S1-O22

Cite this article as: Bojak et al:: HCN1-mediated interactions of ketamine and propofol in a mean field model of the EEG. BMC Neuroscience 2013 14(Suppl 1):O22.

\section{Submit your next manuscript to BioMed Central} and take full advantage of:

- Convenient online submission

- Thorough peer review

- No space constraints or color figure charges

- Immediate publication on acceptance

- Inclusion in PubMed, CAS, Scopus and Google Scholar

- Research which is freely available for redistribution

Submit your manuscript at www.biomedcentral.com/submit 